\title{
AVANÇOS NA CULTURA DO MARACUJÁ NO BRASIL ${ }^{1}$
}

\author{
LAURA MARIA MOLINA MELETTI²
}

\section{INTRODUÇÃO}

O gênero Passiflora possui um grande número de espécies, mais de 400 , sendo cerca de 120 nativas do Brasil (BERNACCI, 2003). Apesar disso, os cultivos comerciais do País baseiam-se numa única espécie, o maracujá-amarelo ou azedo (Passiflora edulis), que representa mais de 95\% dos pomares, devido à qualidade dos seus frutos, vigor, produtividade e rendimento em suco (MELETTI; BRÜCKNER, 2001).

Esse maracujá, o mais consumido na forma de sucos, foi considerado uma fruta de pomar doméstico durante muitos anos, em razão de suas propriedades medicinais. Seu valor comercial foi descoberto bem mais tarde, no final da década de 60 , quando os primeiros pomares paulistas foram instalados. Historicamente, trata-se de um curto período de produção, representado por apenas 40 anos, bastante significativo ao se considerar que o País é o maior produtor mundial de maracujá-amarelo, há mais de duas décadas.

O maracujá-amarelo é uma fruteira tropical nativa, cujo cultivo tem evoluído muito rapidamente no País. Até o início da década de 70, o Brasil nem constava entre os principais países produtores. Por falta de demanda constante do produto, ciclos de retração e expansão da área cultivada alternavam-se. A cultura adquiriu expressão econômica a partir de 1986, quando a ampliação significativa na área cultivada e na produção conduziu à profissionalização da atividade (RIZZI et al., 1998).

A cultura do maracujá vem ocupando um lugar de destaque na fruticultura tropical, um segmento que se expandiu como um todo nos últimos 30 anos. Considerada como uma alternativa agrícola interessante para a pequena propriedade cafeeira, é a fruteira que mais tem atraído os produtores. Representa uma boa opção entre as frutas por oferecer o mais rápido retorno econômico,bem como a oportunidade de uma receita distribuída pela maior parte do ano. A maioria das outras frutas leva alguns anos para entrar em produção, o que é incompatível com a necessidade imediata de renda dos produtores, descapitalizados com os prejuízos resultantes de outras atividades agrícolas (MELETTI et al., 2010).

Durante os primeiros anos de produção, conduzidos com quase total amadorismo, a maioria dos produtores nem era fruticultor (RUGGIERO, 1987). Eram cafeicultores entrando na atividade, animados com a possibilidade de elevado retorno financeiro oferecidos pelo maracujá. A cultura não apresentava ainda expressão econômica, mas, num dos períodos de baixa na cafeicultura, esses produtores migraram para a fruticultura. O pequeno proprietário de agricultura familiar encontrou no maracujá uma opção técnica e economicamente viável. Foi assim que a cultura se desenvolveu. Até hoje, a agricultura familiar tem sido responsável pela expansão dos pomares comerciais.

No período de 1990 a 1996, observou-se uma ampliação significativa da área cultivada com maracujá no País inteiro. Em 1990, foram colhidos cerca de 25 mil hectares, que se ampliou para $32 \mathrm{mil}$ hectares em 1992 e chegou a 44 mil hectares, em 1996. Isso corresponde a um acréscimo de área em torno de $75 \%$, em apenas seis anos.

Depois disso, muitos outros ciclos de retração e expansão da cultura foram observados (Figura 1), definidos por dificuldades cíclicas de comercialização e/ou concentração de problemas fitopatológicos. A evolução da área colhida com maracujá no Brasil, assim como a produção brasileira entre 1996 e 2009, pode ser observada na Tabela 1.

A década de 90 foi marcada pela valorização do preço da fruta fresca. Isto mudou o hábito de consumo do maracujá: por um longo período, cerca de $30 \%$ da produção eram reservadas ao mercado in natura e $70 \%$ seguiam para a indústria de sucos. Por volta de 1998, essa situação inverteu-se. Na década seguinte, cerca de $50 \%$ da produção foram destinadas a cada um desses segmentos. Mais recentemente, $60 \%$ da produção são destinadas ao consumo de frutas frescas, sendo o restante destinado às agroindústrias de processamento. O suco é o principal produto derivado (FERRAZ; LOT, 2006).

Assim, o maracujá-amarelo tem ocupado um lugar de destaque na fruticultura, mesmo quan-

\footnotetext{
${ }^{1}$ Palestra Sinfruit 215 - Simpósio Internacional de Fruticultura - Avanços na Fruticultura (17 a 21 Outubro) ${ }^{2}$ Dra., Pesquisadora Científica, INSTITUTO AGRONÔMICO, Caixa Postal 28, CEP 13.012-970, Campinas-SP. E-mail: lmmm@iac.sp.gov.br
} 
do comparado a outras frutas tropicais com maior tradição de consumo. Sua participação no mercado de hortifrutigranjeiros é garantida, adequando-se perfeitamente a este segmento que valoriza produtos de alto valor agregado (MELETTI et al., 2010).

A região Nordeste tem liderado a produção brasileira nos últimos anos, sendo responsável por metade da produção nacional, em 1996, seguida pelas regiões Sudeste, Norte, Centro-Oeste e Sul. Uma alteração significativa na distribuição geográfica dos pomares tem sido apontada por Gonçalves e Souza (2006): o Pará, que se destacou como principal produtor por alguns anos, cedeu espaço para os pomares da Bahia, Ceará e Espírito Santo, os 3 maiores produtores em 2006. O mesmo ocorre em São Paulo, grande produtor do início da década de 90, com área de produção reduzida significativamente, em função da elevada incidência de viroses (MELETTI et al., 2010).

Várias agroindústrias de sucos foram surgindo em diversos estados, estimulando ainda mais a expansão da atividade. Na última década, o maracujá transformou-se numa oportunidade de capitalização, em curto prazo.

Neste contexto, a produção brasileira de maracujá cresceu, avançando de 409 mil a 713 mil toneladas entre 1996 e 2009, mesmo com o decréscimo da área cultivada entre 1996 e 2006, que se recuperou posteriormente (Tabela 1). O avanço da produção resulta de um progresso tecnológico, que elevou a produtividade em todas as regiões geográficas.

Este aumento na produtividade pode ser explicado, de um lado, pela integração de bons produtores à cultura, mais a adoção da tecnologia de produção recomendada para a cultura, a utilização de sementes selecionadas e cultivares híbridas lançadas pelo Instituto Agronômico em 1999, de alta produtividade (MELETTI, 1999), e pela EMBRAPA, em 2008 (EMBRAPA, 2008), somadas a qualidade das mudas na instalação dos pomares. Outro incentivo foi dado pelo preço do produto, sempre atrativo, apesar das flutuações.

A exportação de maracujá ainda é incipiente. Tem ocorrido em pequena escala, sob as formas de fruta fresca, e, principalmente, suco concentrado. Os principais destinos são os países europeus. A participação da fruta fresca no total das exportações de maracujá do Brasil tem-se restringido a $1,5 \%$, porque o mercado interno absorve quase a totalidade da produção. Os sucos concentrados representam a maior parcela da exportação, alcançam as melhores cotações e ganhos em divisas, sendo atualmente comercializado mais intensamente com Holanda, Estados Unidos, Porto Rico, Japão e Alemanha, os quais importam $76 \%$ do suco concentrado produzido no Brasil.

\section{CARACTERÍSTICAS DA PRODU- ÇÃO DO MARACUJÁ}

O maracujazeiro é cultivado em pequenas propriedades, a maioria com pomares de 3 a 5 hectares. Embora seja uma cultura de alto risco, devido à grande suscetibilidade a doenças, por utilizar insumos de alto valor aquisitivo e de ser necessário atender à exigência de qualidade dos mercados a que se destina, tem sido uma atividade bastante atrativa, pelo alto valor agregado da produção.

Os pomares tornaram-se importantes também na fixação da mão de obra rural. O nível de empregabilidade é elevado, o que confere forte caráter social à cultura. Especialistas apontam que cada hectare de maracujá gera 3 a 4 empregos diretos e ocupa 7 a 8 pessoas, nos diversos elos da cadeia produtiva.

Apesar disso, a constante alteração de área cultivada (Tabela 1) reforça a característica itinerante do maracujá. Em parte, isso se deve ao elevado número de doenças que vão se acumulando nas regiões tradicionais de cultivo e a intensidade dos danos resultantes, por falta de variedades resistentes.

\section{PRINCIPAIS AVANÇOS NA CUL TURA}

Em maracujazeiro, a maior contribuição aos pomares foi dada pelo melhoramento genético. $\mathrm{Na}$ década de 90, observou-se a consolidação de equipes multidisciplinares de pesquisa, em diferentes centros nacionais, cujo resultado foi o lançamento das primeiras cultivares de maracujá, inicialmente direcionadas apenas para a ampliação da produtividade da cultura, para bancar os altos custos de produção. Até o ano 2000, a maioria dos novos pomares era implantada a partir de sementes de frutos selecionados pelos próprios produtores, obtidos de plantios anteriores ou de frutos do mercado atacadista. Isso ocorria por falta de opção, uma vez que o comércio de sementes selecionadas, de boa qualidade, não estava ainda estabelecido, nem existiam cultivares de maracujá.

A partir de 2000, estas equipes desenvolvem pesquisas bastante sedimentadas em novas tecnologias, com objetivos definidos, multiplicidade de métodos e, mais recentemente, com a adoção de ferramentas importantes para o melhoramento genético, como a biotecnologia.

\subsection{AS PRIMEIRAS CULTIVARES - INÍCIO DOS ANOS 2000}

O lançamento das primeiras cultivares de 
maracujá - híbridos mais produtivos e com qualidade de fruta diferenciada para os dois segmentos de mercado (frutas frescas e agroindústria)-transformou o cenário produtivo brasileiro. Com a criação de um sistema organizado de produção e comercialização de sementes das cultivares IAC e mudas selecionadas, ampliaram-se significativamente a qualidade e a produtividade dos pomares.

Esses híbridos foram lançadas em 1999 pelo Instituto Agronômico (IAC), para atender à especialização do mercado. Frutas para o mercado in natura precisam ser maiores e mais pesadas, com homogeneidade, para facilitar a classificação dos frutos. A cultivar de agroindústria deve ter maior rendimento em polpa, maior teor de sólidos solúveis totais (SST), polpa de coloração mais intensa e casca mais fina. Surgiram, então, cultivares direcionadas a cada segmento, cv. IAC 273 (Monte Alegre) e cv. IAC 277 (Joia) - Figuras 2 e 3, para frutas frescas, e cv. IAC 275 (Maravilha), para agroindústria (Figura 4), com características distintas (MELETTI, 2000; MELETTI et al., 2005). Os produtores puderam, assim, direcionar sua produção em função do mercado que desejavam atingir.

No início da década de 2000, a cv. Casca Fina - CCF também foi registrada para cultivo (NASCIMENTO et al., 2003), mas a indisponibilidade de sementes e de um sistema organizado de produção fez com que a mesma fosse cultivada apenas regionalmente, no PA, onde foi desenvolvida.

Sementes das cultivares IAC tornaram-se disponíveis em larga escala para os produtores, sendo comercializadas ininterruptamente de 2000 até os dias de hoje. A demanda tem sido crescente ano a ano, em função da qualidade e da produtividade que atingem. Com garantia de origem, certificado de sanidade e registradas no Ministério da Agricultura, as sementes têm sido adquiridas por produtores de todos os estados, o que resultou na ampliação significativa da produtividade. Em pomares que utilizam sementes melhoradas, associadas à tecnologia de produção recomendada para a cultura, a produtividade passou da média nacional de 10 a 15 t/ha para os atuais 4550 t/ha.

\subsection{NOVAS CULTIVARES - FOCO NA TOLE- RÂNCIA A DOENÇAS}

Com o passar dos anos, os pomares foram sendo afetados por muitas doenças. Por isso, tornou-se necessária a obtenção de cultivares com resistência a moléstias, seja incorporando genes de resistência nas atuais cultivares-elite, seja no desenvolvimento de novas cultivares. Os patógenos mais visados são aqueles que causam moléstias de ocorrência generalizada, algumas de âmbito nacional. Em algumas regiões com histórico de incidência, há moléstias limitantes para a cultura, nos casos em que não se conhece controle químico eficiente e/ou econômico para elas, até o momento. Destacam-se: virose do endurecimento dos frutos (woodness), bacteriose (Xanthomonas axonopodis pv. passiflorae) e fusariose (Fusarium oxysporum).

Três novos maracujás híbridos foram obtidos por meio das pesquisas da EMBRAPA - Cerrados (Planaltina-DF), sendo plantados em fase experimental desde o lançamento, ocorrido em 2008 durante o XX Congresso Brasileiro de Fruticultura (Vitória-ES). Com os primeiros resultados, os pesquisadores consideraram que as frutas geneticamente modificadas, BRS Gigante Amarelo, BRS Sol do Cerrado e BRS Ouro Vermelho apresentam diversas vantagens quando comparadas às tradicionais (EMBRAPA, 2008). Pôde ser observada alta produtividade, com colheitas superiores a 50 toneladas anuais por hectare-a média das convencionais não híbridas é de 14 toneladas-resistência a diversas espécies de fungos, bactérias e vírus, e ausência de alteração nos valores nutricionais das frutas. $\mathrm{O}$ peso médio da versão melhorada geneticamente fica entre 120 e 350 gramas-o tradicional tem média de 100 a 160 gramas. Além disso, o novo maracujá tem cerca de 15\% a mais de vitamina C e mais polpa.

Segundo informações oriundas da EMBRAPA-Cerrados, os impactos ambientais também foram reduzidos no processo produtivo desses maracujás. A diminuição do uso de defensivos agrícolas, pela incorporação de resistência múltipla a doenças, além de diminuir os resíduos, resultará na melhoria e otimização do uso de recursos naturais pela maior produção por unidade de área.

Informações no site da EMBRAPA-Cerrados indicam que o híbrido de maracujazeiro-azedo BRS Gigante Amarelo é de alta produtividade. Nas condições do Distrito Federal, por exemplo, a produtividade tem alcançado $42 \mathrm{t} / \mathrm{ha}$ no primeiro ano, mesmo com ataque de virose. No segundo ano de produção, a produtividade fica em torno de 20 a 25 t/ha, dependendo do manejo. A coloração externa dessa variedade é amarelo brilhante, e a polpa é de cor amarelo forte (maior quantidade de vitamina $\mathrm{C}$ ). Tem boa tolerância à antracnose e bacteriose, mas é suscetível à virose, verrugose e às doenças causadas por patógenos de solo. Não há informação sobre maiores danos causados por pragas.

A BRS Ouro Vermelho é o híbrido de maracujazeiro-azedo com maior quantidade de vitamina C, com a polpa de cor amarelo forte (Figura 6). A 
produtividade, nas condições do Distrito Federal, tem ficado em torno de $40 \mathrm{t} / \mathrm{ha}$ no primeiro ano, sem a polinização manual. É tolerante a doenças foliares, incluindo a virose. Em diferentes locais, tem-se comportado como tolerante, embora estirpes mais severas tragam alterações no comportamento esperado.

O híbrido BRS Sol do Cerrado também tem coloração externa amarelo- brilhante e coloração de polpa amarelo forte (Figura 7), apresentando frutos de grande tamanho. A produtividade nas condições do Distrito Federal, assim como o BRS Ouro Vermelho, chega a $40 \mathrm{t} /$ ha no primeiro ano, sem o uso de polinização manual. No segundo ano, a produtividade fica em torno de 20 a 25 t/ha. Apresenta tolerância a doenças foliares, como bacteriose, antracnose e virose, mas é suscetível a doenças causadas por patógenos de solo (EMBRAPA, 2008).

Esses híbridos não se adaptam a regiões sujeitas a geada. Os três híbridos são resistentes ao transporte e permitem maior tempo de prateleira, por terem casca mais grossa que os outros híbridos do mercado, com bom rendimento da polpa. Seus frutos são para a indústria e mesa.

O pesquisador Fábio Faleiro, integrante da equipe que desenvolveu essas cultivares, considera que os híbridos da Embrapa Cerrados são bem adaptados à região do DF e entorno. "Essas cultivares são importantes para a competitividade do maracujá brasileiro no cenário internacional", afirmou, lembrando que, apesar de o Brasil ser responsável por $80 \%$ da produção mundial do fruto, não é o principal exportador. Uma das vantagens da variedade BRS Ouro Vermelho destacadas por Faleiro é a maior tolerância à virose. Já a BRS Sol do Cerrado tem menor dependência da polinização manual (EMBRAPA, 2008). O Instituto Agronômico (IAC) e a EMBRAPA co- mercializam as sementes de suas cultivares diretamente, não havendo por isso em casas de produtos agropecuários. O objetivo é garantir a origem e a identidade do material, por serem híbridos cruzados manualmente, em condições de telado, protegidos de contaminação por pólen estranho.

\subsection{OUTROS AVANÇOS}

A enxertia do maracujá-amarelo sobre outras espécies não cultivadas, visando ao controle da morte prematura de plantas ou da fusariose é uma realidade. Uma tecnologia desenvolvida na UNESP-Jaboticabal, totalmente viável, sendo a enxertia hipocotiledonar a mais indicada. Para as regiões afetadas por patógenos de solo, plantas enxertadas tornam o cultivo possível. Mas a aplicação do processo em escala comercial ainda tem-se mostrado antieconômica, devido à pequena disponibilidade das sementes das espécies porta-enxerto, além da dificuldade e irregularidade de germinação da maioria.

A biotecnologia tem apresentado diversas técnicas passíveis de utilização como ferramenta ao melhoramento, sendo as transformações genéticas as mais bem-sucedidas. Plantas de maracujá-amarelo já foram transformadas geneticamente, visando à obtenção de cultivares resistentes ao endurecimento do fruto (VEFM). Para que estas plantas causem o impacto esperado na produção como uma forma de controle eficiente para o VEFM e para o qual não existem medidas de controle satisfatórias no momento, é preciso a confirmação da resistência de amplo espectro de ação, com a inoculação de vários isolados do vírus, ainda em curso (FALEIRO et al., 2005; MONTEIRO-HARA et al., 2011).

TABELA 1 - Evolução da área colhida (x 1.000 ha) com maracujá-amarelo no Brasil, e da produção brasileira (x 1.000 t), no período de 1989 a 2009.

\begin{tabular}{lll}
\hline Brasil & $\begin{array}{l}\text { Área colhida } \\
(\mathrm{x} 1.000 \text { ha })\end{array}$ & $\begin{array}{l}\text { Produção brasileira } \\
(\mathrm{x} 1.000 \mathrm{t})\end{array}$ \\
\hline 1989 & 28.259 & 259 \\
1990 & 25.329 & 317 \\
1991 & 30.808 & 380 \\
1992 & 32.617 & 418 \\
1993 & 32.539 & 360 \\
1995 & 38.522 & 405 \\
1996 & 44.462 & 409 \\
1998 & 33.012 & 298 \\
1999 & 35.637 & 317 \\
2000 & 33.428 & 331 \\
2001 & 33.039 & 467 \\
\hline
\end{tabular}




\begin{tabular}{lll}
\hline 2002 & 34.778 & 479 \\
2003 & 34.994 & 485 \\
2004 & 36.576 & 492 \\
2005 & 35.820 & 480 \\
2006 & 44.363 & 615 \\
2007 & 46.866 & 664 \\
2008 & 48.752 & 684 \\
2009 & 50.795 & 713 \\
\hline
\end{tabular}

Fonte: IBGE (AGRIANUAL, 2001); IBGE - Produção Agrícola Municipal (2009).

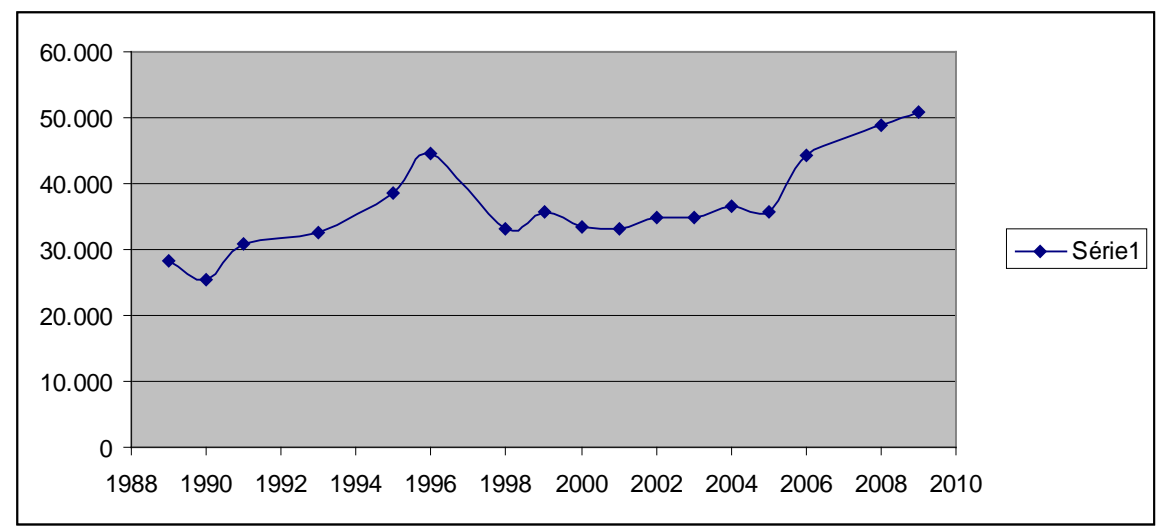

FIGURA 1- Oscilação da área colhida com maracujá no Brasil (ha), no período de 1989 a 2009. Fonte: IBGE (2009).

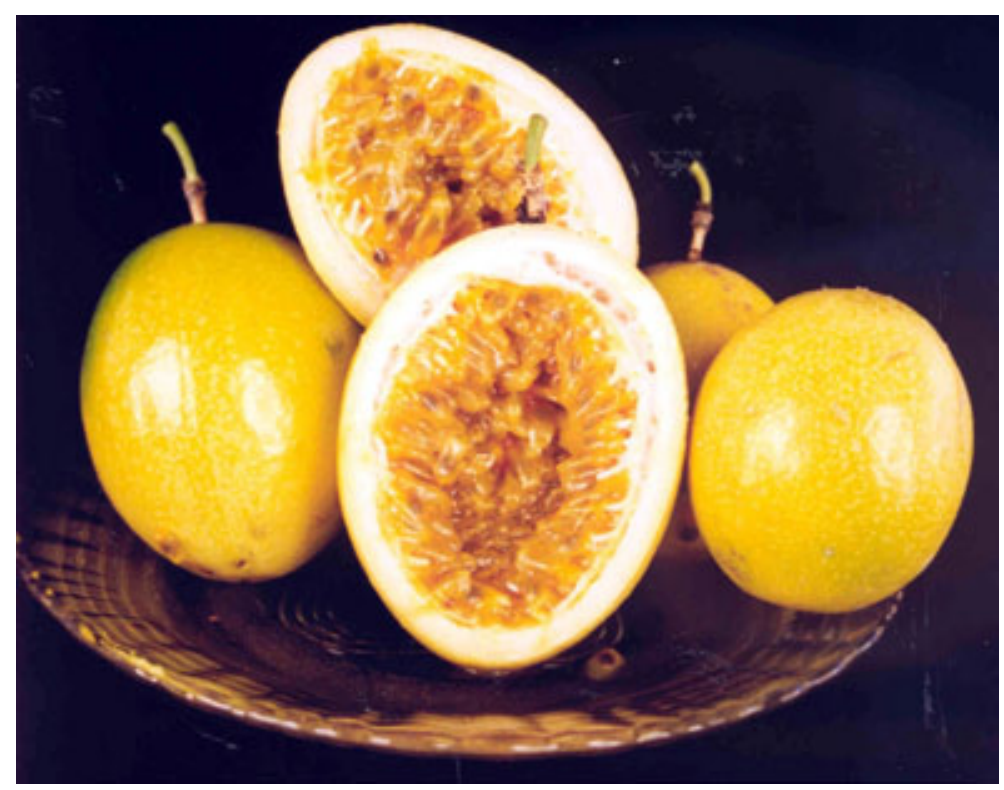

FIGURA 2 - Frutos da cv. IAC 273 (Monte Alegre), desenvolvidos para o mercado de frutas frescas. Frutos maiores e mais pesados, com homogeneidade.

Foto: L.M.M.MELETTI (2001). 


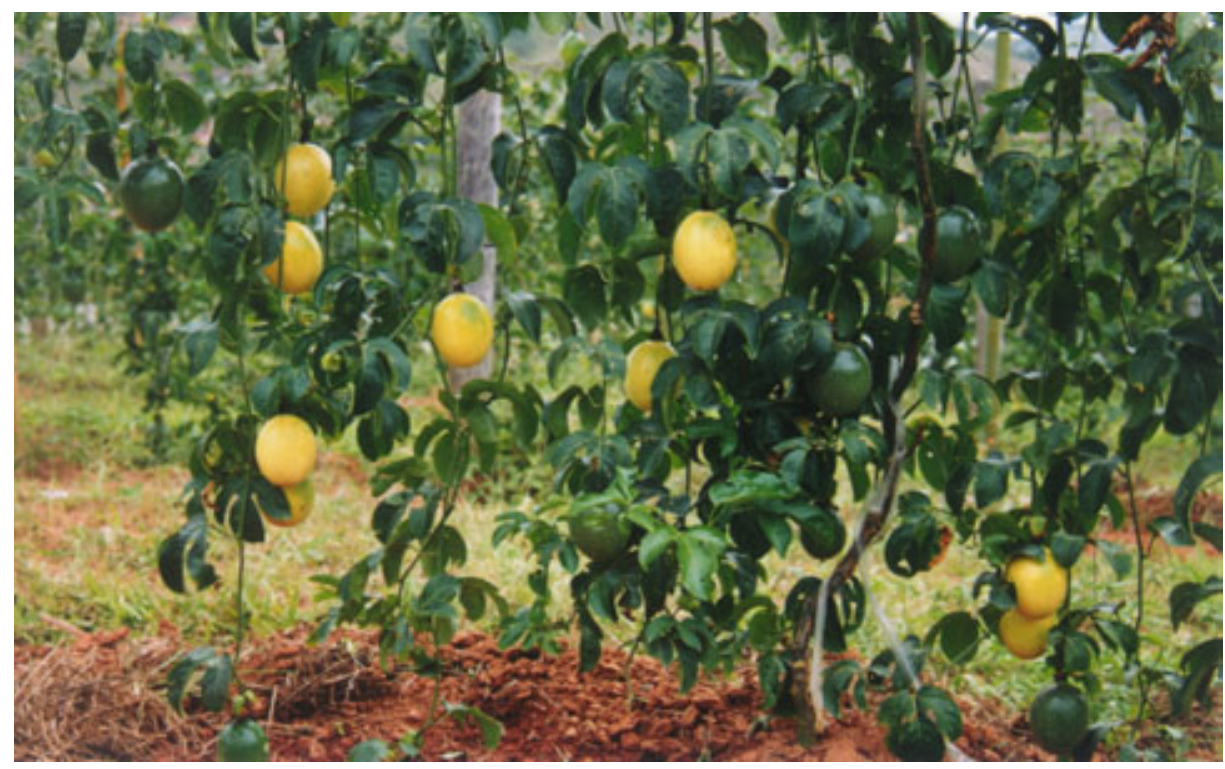

FIGURA 3 - Frutos da cv. IAC 277 (Jóia), desenvolvidos para o mercado de frutas frescas. Frutos homogêneos, alta produtividade (45 a 50 t/ha).

Foto: L.M.M.MELETTI (2000).

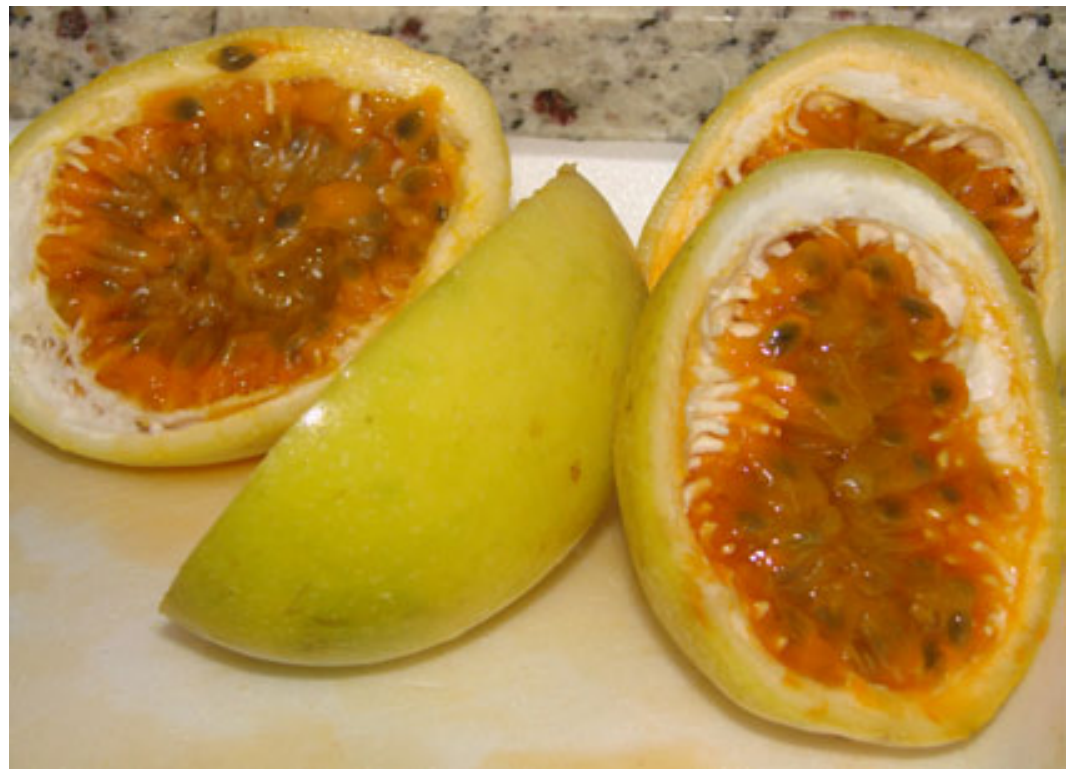

FIGURA 4 - Frutos da cv. IAC 275 (Maravilha), desenvolvidos para a agroindústria. Frutos com casca fina, cavidade interna completamente preenchida, alto teor de SST e maior rendimento em polpa.

Foto: L.M.M. MELETTI (2004) 


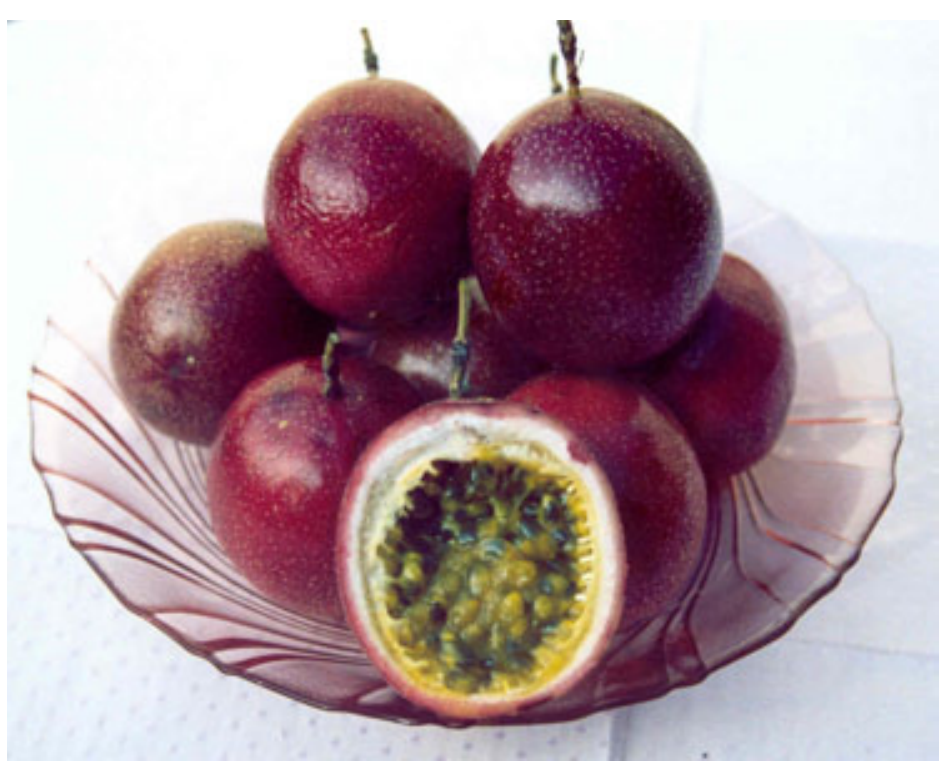

FIGURA 5 - Frutos da cv. IAC Paulista, maracujá-roxo. Frutos menos ácidos, desenvolvidos para exportação. Foto: L.M.M.MELETTI (2007)

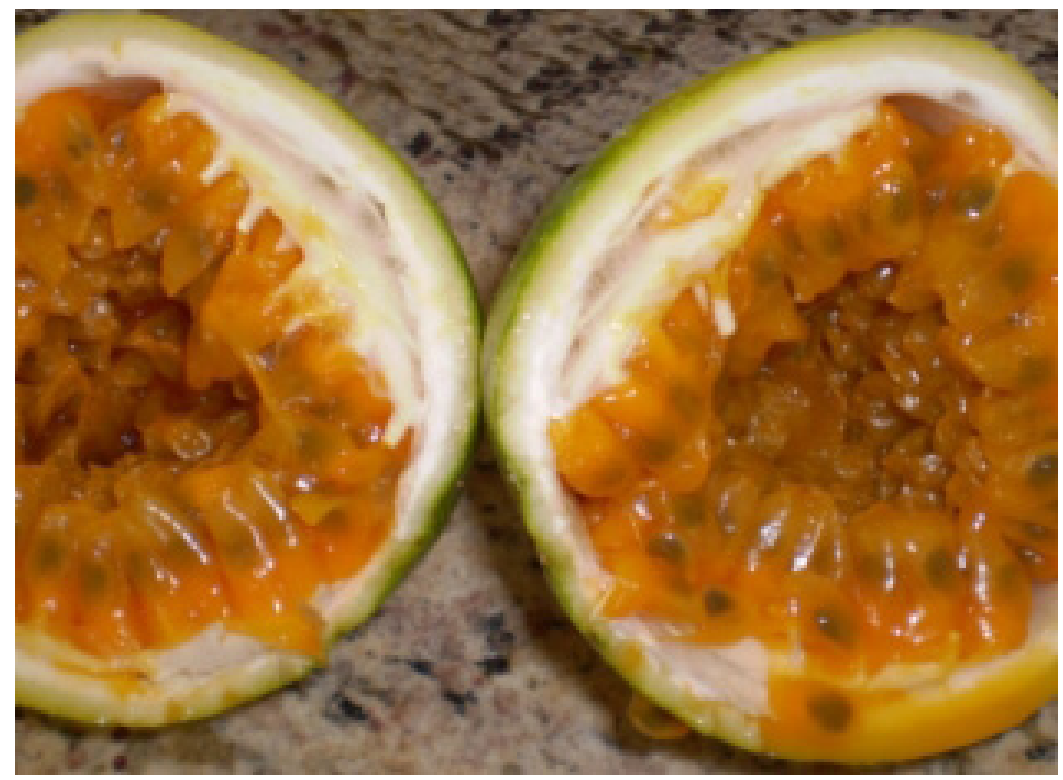

FIGURA 6 - BRS Ouro Vermelho é o híbrido de maracujá-azedo com maior quantidade de vitamina C. Foto: Divulgação Embrapa 


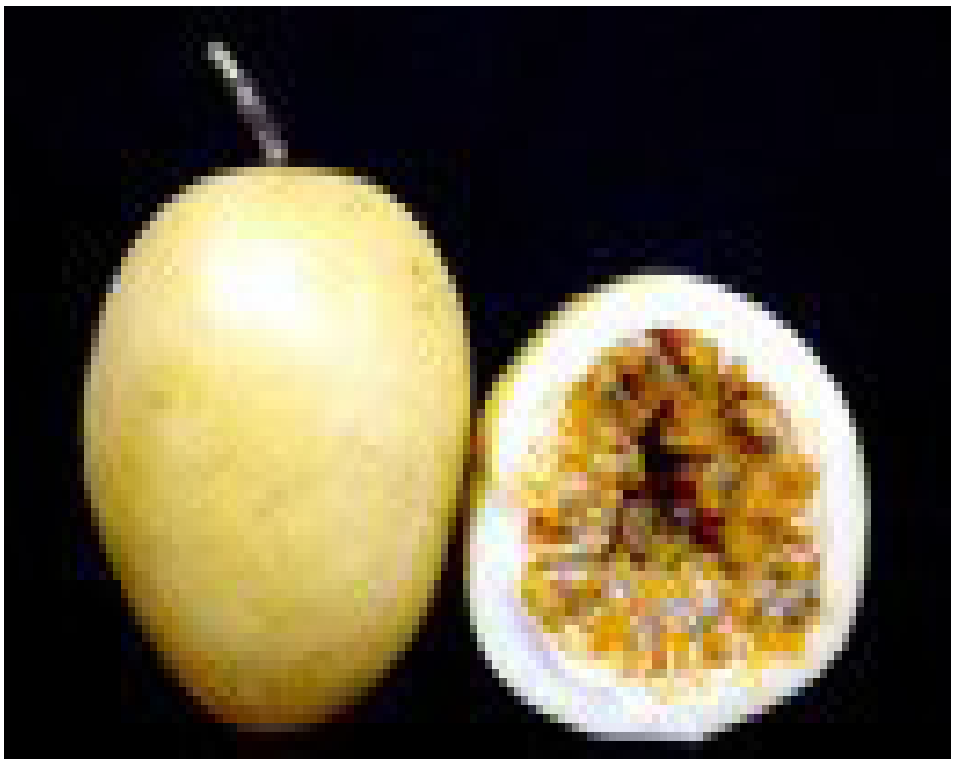

FIGURA 7 - BRS Sol de Cerrado.

Foto: Divulgação EMBRAPA.

\section{REFERÊNCIAS}

AGRIANUAL: anuário da agricultura brasileira. São Paulo: FNP, 2009. p. 371-376.

BERNACCI, L.C. Passifloraceae. In: WANDERLEY, M.G.L.; SHEPHERD, G.J.; GIULIETTI, A.M.; MELHEM, T.S. (Ed.). Flora fanerogâmica do Estado de São Paulo. São Paulo: RiMa, FAPESP, 2003. v.3, p. 247-248.

EMBRAPA. Notícias. 2008. Disponível em: $<\underline{w w w}$. embrapa.br/notícias>. Acesso em : 30 jun. 2011.

FALEIRO, F.G; JUNQUEIRA, N.T.V.; BRAGA, M.F. Maracujá: germoplasma e melhoramento genético. Planaltina: EMBRAPA Cerrados, 2005.v. $1,677 \mathrm{p}$.

FERRAZ, J.V.; LOT, L. Fruta para consumo in natu$r a$ tem boa perspectiva de renda. In: AGRIANUAL 2007: anuário da agricultura brasileira. Maracujá. São Paulo: FNP Consultoria e Comércio, 2006. p. 387-388.

IBGE - Instituto Brasileiro de Geografia e Estatística. Maracujá: área plantada e quantidade produzida. Brasília, 2009. (Produção Agrícola Municipal, 2009). Disponível em: <http://www.sidra.ibge.gov.br>. Acesso em: 20 jun. 2011.
GONÇALVES, J.S.; SOUZA, S.A.M. Fruta da paixão: panorama econômico do maracujá no Brasil. Informações Econômicas, São Paulo, v.36, n.12, p.29-35, dez 2006.

MELETTI, L.M.M. Maracujá 'Joia’ (IAC-277), 'Maracujá-Maçã', 'Maracujá-Maravilha’ (IAC-275), 'Maracujá-Monte-Alegre' (IAC-273). In: DONADIO, L.C. (Ed.). Novas variedades brasileiras de frutas. Jaboticabal: Sociedade Brasileira de Fruticultura, 2000. p. 152-159.

MELETTI, L.M.M.; BRÜCKNER, C.H. Melhoramento Genético. In: BRÜCKNER, C.H.; PICANÇO, M.C. Maracujá: tecnologia de produção, pós-colheita, agroindústria, mercado. Porto Alegre: Cinco Continentes, 2001. p. 345-385.

MELETTI, L.M.M.; OLIVEIRA, J.C.; RUGGIERO, C. Maracujá. Jaboticabal: FUNEP, 2010. (Série Frutas Nativas, 6.)

MELETTI, L.M.M ; SOARES-SCOTT, M. D.; BERNACCI, L.C.; PASSOS, I. R. da S. . Melhoramento genético do maracujá: passado e futuro. In: FALEIRO, F.G.; JUNQUEIRA, N. T. V.; BRAGA, M.F. (Org.). Maracujá: germoplasma e melhoramento genético. Planaltina: EMBRAPA CERRADOS, 2005. v. 1, p. 55-78. 
MONTEIRO-HARA, A.; JADÃO, A.S.; MENDES, B .M.J.; TREVISAN, F.; REZENDE, J.A.M.; VIEIRA, M.L.C.; MELETTI, L.M.M.; PIEDADE, S.M.S. Genetic Transformation of Passionflower and Evaluation of R1 and R2 Generations for Resistance to Cowpea aphid borne mosaic virus. Plant Disease, St Paul, v. 95, n.8, p. 1021-1025, 2011.

NASCIMENTO, W.M.O.; TOMÉ, A.T.; OLIVEIRA, M.S.P. de; MULLER, C.H.; CARVALHO, J.E.U . Seleção de progênies de maracujazeiro-amarelo (Passiflora edulis f. flavicarpa) quanto à qualidade de frutos. Revista Brasileira de Fruticultura, Jaboticabal, v. 25, n.1, p.186-188, 2003.
RIZZI, L.C.; RABELLO, L. A.; MOROZINI FILHO, W.; SAVASAKI, E.T.; KAVATI, R. Cultura do maracujá-azedo. Campinas: Coordenadoria de Assistência Técnica Integral, SAA, 1998. 23 p. (Boletim Técnico, 235).

RUGGIERO, C. (Ed.). Cultura do maracujazeiro. Ribeirão Preto: Legis Summa, 1987. p.218-246. 